\title{
The Use of Pictorial Illustrations in African Language Dictionaries*
}

\author{
Lilian Gangla-Birir, Unit for Language Skills Development, University of \\ Pretoria, Pretoria, Republic of South Africa (kenyan@mweb.co.za)
}

\begin{abstract}
This article examines the use of pictorial illustrations in African language dictionaries, with particular reference to items generally included in dictionaries based on Stein's (1991) categories. It argues for the need to include more illustrations of cultural items specific to a particular community and language group in dictionaries. A corpus analytic survey is done to determine if African language dictionaries employ pictorial illustrations and, if so, which items are illustrated. The results of this survey indicate that only a few African language dictionaries employ pictorial illustrations, even those that do correspond to Stein's categories. Of the dictionaries examined, only one uses illustrations in the form of full-colour photographs, namely of different kinds of cattle, a very important cultural item within that specific community.
\end{abstract}

Keywords: PICTORIAL ILLUSTRATIONS, CULTURE, LEXICOGRAPHY, BILINGUAL DICTIONARY, MONOLINGUAL DICTIONARY, AFRICAN LANGUAGE

Opsomming: Die gebruik van beeldillustrasies in Afrikataalwoordeboeke. Hierdie artikel ondersoek die gebruik van beeldillustrasies in Afrikataalwoordeboeke met spesiale verwysing na items wat gewoonlik in woordeboeke ingesluit word, gebaseer op Stein (1991) se kategorieë. Dit betoog vir die noodsaaklikheid om meer illustrasies van kulturele items eie aan 'n besondere gemeenskap of taalgroep in woordeboeke in te sluit. ' $n$ Analitiese oorsig van ' $n$ korpus is gedoen om te bepaal of Afrikataalwoordeboeke beeldillustrasies gebruik, en, indien wel, watter items geillustreer word. Die resultate van hierdie oorsig toon aan dat slegs ' $n$ paar Afrikataalwoordeboeke beeldillustrasies gebruik, selfs dié wat met Stein se kategorieë ooreenstem. Van die woordeboeke wat ondersoek is, gebruik net een illustrasies in die vorm van volkleurfoto's, naamlik van verskillende soorte beeste, ' $n$ baie belangrike kulturele item binne daardie spesifieke gemeenskap.

Sleutelwoorde: BEELDILLUSTRASIES, KULTUUR, LEKSIKOGRAFIE, TWEETALIGE WOORDEBOEK, EENTALIGE WOORDEBOEK, AFRIKATAAL

\section{Introduction}

The role and function of pictorial illustrations for educational purposes cannot be overemphasised. Despite various studies carried out to determine the exact contribution of illustrations to learning and knowledge acquisition, the find-

* This article is based on two chapters of an unpublished M.A. thesis by L.A. Gangla, Pictorial Illustrations in Dictionaries, completed in 2001 at the University of Pretoria, Pretoria, Republic of South Africa. 
ings have varied significantly. However, education systems are to a large extent based on reading and writing and most source materials are produced in written form. Among the source materials used within education systems are dictionaries which are written to serve different purposes. These are divided into two main categories: dictionaries that focus on language (linguistic dictionaries) and those that focus on the world (encyclopaedic dictionaries) (cf. Zgusta 1971, Carstens 2001).

Zgusta (1988) states that, since the dictionary is a text couched in natural language, it possesses pragmatic aspects itself. In this article, the role of illustrations in conveying cultural information in monolingual and bi- or multi-lingual dictionaries is dealt with. Though an examination of the included pictorial illustrations was done, at this stage the purpose of the dictionary survey was to investigate which objects, if any, are illustrated in these dictionaries. It was attempted to establish if there is a kind of pattern in what is illustrated. Fleming (1967: 247) defines pictorial illustrations as 'those configurations of line, dot or area and any combination of these three resembling events or objects (persons, places and/or things) either as perceived or as generally conceived'. Al-Kasimi (1977: 77) comments that the definition should be expanded to include such borderline cases as number lines, geometric figures, structural chemical formulas, curves, graphs and time lines. Putter (1999: 51) regards the use of illustrations in dictionaries as a type of definition, which is known in lexicography as 'ostensive definition' or 'ostensive addressing' (in Gouws' terminology). It is normally a type of definition that is used to augment and to elucidate the verbal definition (Gouws 1989: 168; Swanepoel 1990: 186).

\section{The inclusion of encyclopaedic information in dictionaries}

For a long time, in the history of lexicography, a strict distinction was made between linguistic and encyclopaedic (pragmatic, real-world) information. During the nineties, lexicographers came to realize that part of what is known about the meaning of a word belongs to what is known about the surrounding world. This realization led to a less strict division between linguistic and encyclopaedic information, and between dictionaries and encyclopaedias.

Cultural information is a type of information that merits the inclusion of illustrations in dictionaries. In itself it may be regarded as a type of encyclopaedic information. Illustrations may serve as vehicles to clarify and/or disambiguate the meanings of culture-specific words. Lexicographers also came to realize that the criteria for inclusion of illustrations in different types of dictionaries might differ on the basis of the cultural differences between dictionary users and the culture in which the target language is embedded. This gap would, for instance, determine how much encyclopaedic information should be presented to bridge the gap. Pedagogical dictionaries would particularly benefit from the inclusion of encyclopaedic information, such as illustrations. Due to their comprehensiveness, certain overall descriptive dictionaries, such as the Woordeboek van die Afrikaanse Taal (WAT), in its first volumes, included several illustrations. 


\section{Metalexicographical perspectives on the function and use of illustra- tions in dictionaries}

Gouws (1994: 61) argues that pictorial illustrations can be employed as a microstructural type to enhance semantic disambiguation. He further adds that pictorial illustrations have a semantic importance, a lexicographical function and a range of applications, and although the primary utilization of ostensive addressing is found in the differentiation of senses in equivalent relations of semantic divergence, they are also used extensively where a lemma has a low degree of translatability. The explicitness that can be achieved through the use of pictorial illustrations enhances the retrieval of information. This applies to both monolingual descriptive and translation dictionaries. Al-Kasimi (1977) argues that pictorial illustrations should be systematically and consistently employed in bilingual dictionaries, not for the purpose of advertisement but as an essential lexicographical device.

\section{The role of culture in the compilation of dictionaries}

Culture is defined as that complex whole which includes knowledge, beliefs, arts, morals, law, custom and any other capabilities and habits acquired by man as a member of society (Tylor 1871 in Ocholla-Ayayo 1980: 2). Casson (1981: 17), on the other hand, defines culture as 'idealised cognitive social systems of knowledge, beliefs, and value that exist in the collective minds of individual members of society. It is the mental equipment that society members use in orienting, transacting, discussing, defining, categorising, and interpreting social behaviour in their society.' It is the means by which society members generate appropriate social behaviour and appropriately interpret the behaviour of others.

The lexicographical history of African languages has been dominated by bilingual lexicography. There are, however, a number of monolingual dictionaries in some of the African languages. The users of these dictionaries vary from mother-tongue speakers, to second language speakers to foreign learners. An examination of the cultural setting and the equivalence in bilingual dictionaries reveals that language does not exist in a vacuum but occurs in context. Hence, relationships between the various languages as well as within a language become clear. One of the important aspects is the cultural context in which a word is used. The cultural context determines its meaning and to a large extent also the ability of a lexicographer either to translate the word into another language or to describe it in another language.

The relationship between language and culture is a major issue in crosscultural communication. Ndoleriire (2000: 272) points out that language can be considered a cultural practice, and that it is both an instrument to and a product of culture. He further adds that 'the different languages spoken by different groups of people who have the same culture are used to express cultural norms 
and practices which are the same in those groups of people'. Therefore, it is apparent that culture is learnt through human interaction and linguistic communication and that both language and communication are functions of culture. According to the Sapir-Whorf hypothesis, language and culture are intimately related and language provides a key to understanding culture. This statement further indicates that language is an important instrument in the totality of culture. The degree of misunderstanding between cultures depends on the degree of difference between the cultures concerned. Language is a part of culture and culture is a part of language; the two are so intricately interwoven that they cannot be separated without losing the significance of either language or culture (Brown 1987: 123).

Ndoleriire (2000: 274) further exemplifies that 'individual people learn the values, norms, beliefs, views, and behavioural patterns of their group through linguistic interaction and groups give expression to their cultural identities, and practise their cultural life, not only through music, art, dancing, and dress, but also through language'. Accordingly, the link between peoples' way of life and their language can be clearly seen. Being a written record of this language, the dictionary must find a way to carry on the peoples' culture as part of their written heritage. Language is the key component of the dictionary and therefore the lexicographer needs to look at the best way to describe it. In this regard, where there are semantic gaps due to culture-specific words or ideas, it is important that another way is used to refer to the concept. Pictorial illustrations provide an accurate way of representing the concept, given that the illustrations - whether photographs or line drawings, full colour or black and white illustrations - communicate the idea effectively.

Users of bilingual dictionaries, in particular, may benefit from illustrations. According to Zgusta (1988: 247), the most pragmatically effective equivalent of a word in a bilingual dictionary is a translational one; that is, an equivalent which is the counterpart of the target language lexical unit in all respects, namely with the same denotations, stylistic levels, and collocations. Particularly due to cultural differences, however, incomplete equivalence or the absence of any equivalent is experienced. This is not only limited to culturalbound words but also differences in the pragmatics and ethnology of speaking. This aspect must be taken into account when compiling a dictionary, particularly a bilingual dictionary, and in such instances pictorial illustrations will go a long way in bridging the semantic gap between the languages.

In spite of this, illustrations should not necessarily have a uni-directional function in dictionaries. According to Zgusta (1988: 246), lexicography strongly takes into consideration the culture of the language described. He illustrates this by using as example the Bilingual Dictionary of Zoque (Engel and Allhiser de Engel 1987). This dictionary, which has many illustrations, does not only use them to explain peculiarities of Zoque culture to speakers of Spanish, but they also illustrate Spanish cultural items to Zoque speakers. For instance, there is an illustration of a boy buying something in a shop because objects and situa- 
tions like these belong not so much to Zoque culture as to the culture surrounding them. Thus, the dictionary not only explains 'the Zoque culture to the Spanish but also the Spanish culture to the Zoque, certainly a rather novel attitude in a dictionary of a language of a small, rural group' (Zgusta 1988: 246). This is in contrast to, for instance, the South African Multi-language Dictionary and Phrase Book where the illustrations are more Eurocentric than African. For example, the rooms in a house include a pantry while the sports played are cricket and rugby. This is despite the fact that this is a multi-language dictionary that covers seven languages and apart from English and Afrikaans the rest are African languages (Northern Sotho, Sesotho, Tswana, Xhosa and Zulu).

\section{Material and methods}

In pursuance of this task, a deductive research method was employed, based on existing literature within the field of pictorial illustrations. A survey of dictionaries was done to determine which dictionaries employ pictorial illustrations. The dictionaries were not representative of all the African languages and for some of the languages there was more than one dictionary. This limitation partly due to the fact that the study was limited to dictionaries available in the Merensky Library at the University of Pretoria and additional dictionaries obtained from the Department of African Languages at the University of Pretoria. As a result of this, most of the African language dictionaries are of African languages spoken within South Africa.

The inclusion of English dictionaries was to compare the objects they illustrate to those illustrated in the African language dictionaries and to see if there are any similarities or differences.

\section{Dictionary survey}

Stein (1991: 106) distinguishes four main types of illustrations in dictionaries:

1. Illustrations showing common animals, objects and plants.

2. Illustrations showing things that are not easily explained in words, such as shapes, complex actions, or small differences between words which are similar but not the same.

3. Illustrations depicting groups of related objects with a view to explaining the differences between similar objects, showing the range of shapes and forms covered by a particular word and serving as an important aid to vocabulary expansion.

4. Illustrations showing the basic or physical meaning of words commonly used in an abstract or figurative way. 
Culture-specific terms can be added to the above main types, particularly in African language dictionaries.

\section{Corpus-analytic research}

For this survey, the dictionaries were picked at random and scanned for any form of pictorial illustrations. The purpose of the exercise was to determine which dictionaries make use of pictorial illustrations and which types of lemmas are typically illustrated, making use of Stein's (1991) typology outlined above. The survey further considered the placement of the illustrations: in the front matter, the central text or the back matter of the dictionary.

\section{Results}

Of the dictionaries scanned, only four employed pictorial illustrations, namely Thanodi ya Setswana, a monolingual dictionary, the Bilingual Dholuo-English Dictionary Kenya, the Learner's English-Venda Dictionary Illustrated in Colour and the South African Multi-language Dictionary and Phrase Book, which covers English, Afrikaans, Northern Sotho, Sesotho, Tswana, Xhosa and Zulu.

The only African language monolingual dictionary with pictorial illustrations is Thanodi ya Setswana. It gives full colour pictures of cattle and trees. However, these pictures do not appear in the central text of the dictionary but are given at the end of the dictionary, forming the back matter. The full colour pictures are accompanied by captions that provide the name of the particular cattle or plant in Setswana. The difficulty the lexicographers would have been faced with if they opted to describe the different kinds of cattle or plants can clearly be realised. It would probably not have been as effective as the pictures used. However, there is no cross-reference from the central text to these illustrations in the back matter. The illustrations therefore serve an encyclopaedic, rather than a lexicographical function.

The Bilingual Dholuo-English Dictionary Kenya has line drawings of birds, insects, plants, pots, animals and fish. The dictionary is bi-directional, but the bulk of the illustrations occur in the Dholuo-English section. Of particular relevance are the illustrations of different kinds of pots. In English there is only one word for pot but in Dholuo, a Nilotic language spoken in East Africa, there are several words for the concept pot. In the Dholuo-English section of this dictionary, the lexicographer chooses to lemmatise the different words for pot alphabetically. The illustrations are in the central text of the dictionary.

In the English-Venda Dictionary Illustrated in Colour, two full-colour photographs are incorporated along with a word list in which the headword is lexicalised in English, the word class indicated using appropriate abbreviations and the translations provided in Tshivenda. The photographs are of various activities, items, objects, places, animals, birds, insects and flowers. However, 
the captions of these photographs only contain the name in English. To find the Tshivenda translation, the user will first have to locate the English word in the $\mathrm{A}-\mathrm{Z}$ section where the Tshivenda translation is given. The illustrations therefore are not very effective.

The South African Multi-language Dictionary and Phrase Book has a visual dictionary in the front matter. The contents of the visual dictionary include pictures of the human body, a house plan (lounge, dining-room, kitchen, pantry, bedroom, bathroom, garden), an office, a car (instruments, mechanics) and sports (soccer, rugby, cricket). Though these items are illustrated, these illustrations will not be further analysed as they fall outside the scope of this study which deals particularly with cultural items.

\section{Discussion}

On considering the pictorial illustrations found in the dictionaries surveyed, the ideal criteria as specified by Al-Kasimi (1977: 100-102) have been met. The illustrations are compact as visual noise has been avoided and have fidelity as they are realistically executed. The interpretability of the message conveyed is easily understood. They are relevant as they are related to the user's past environmental and realistic experiences, which are determining factors in the user's success in interpreting the picture. The pictures are simple and precise. The use of captions and titles aid in making the illustrations complete whereas the appropriate size and adequate artistic performance make them clear.

The English dictionaries used for comparison show the inclusion of numerous pictorial illustrations. This may be attributed to a number of factors including a well-developed and highly competitive lexicographical department within the English language industry with a varied target market ranging from first language speakers of English, second language speakers of English and foreign language learners of English with varied needs. The comparison between the English and African language dictionaries was therefore not effective due to a number of factors, including the dissimilar availability of sources.

Based on the findings of the dictionary survey, there is a close correlation between the categories Stein (1991) gives and the items actually illustrated in these dictionaries. The items illustrated across the board include birds, animals, plants and houses. These items fall under Stein's first category of illustrations of common animals, objects, and plants. However, there are differences in the way in which the items are illustrated. In some dictionaries, for example the Bilingual Dholuo-English Dictionary Kenya, the lemma bird in the Dholuo-English section of the dictionary is illustrated according to the Dholuo word for the particular bird, whereas in the other dictionaries different kinds of birds are illustrated under the single lemma bird.

In showing how a dictionary may facilitate the learning of the lexicon of a foreign language, the concept basket (as known in English) shall be considered and compared to the same broad concept in Dholuo. In English, there is only 
one generic word, but, as indicated below, Dholuo has different names for different baskets depending on their shape and function.

In addition to this, the concept cattle (termed cattle in the English-speaking world) will also be considered. It will be compared with the way in which the Batswana lexicalized this concept, and the way a Setswana dictionary has, by making use of illustrations, dealt with the range of lexical items for cattle.

\section{Basket types and their functions among the Luo people of East Africa}

According to Ocholla-Ayayo (1980: 138), it is thought that, in an attempt to establish the Luo cultural pattern, one important method is to look at the sociocultural or socio-economic function of the manufactured objects. The Luo do not use a basket for more than one purpose. Below is a list of a few of the many different types of baskets of the Luo people and their various functions.

\begin{tabular}{|l|l|}
\hline okapu & $\begin{array}{l}\text { Basket made by weaving from the same material, having a } \\
\text { close interwoven pattern and used for transportation, espe- } \\
\text { cially of vegetables. }\end{array}$ \\
\hline aduda-biye & Market basket made by weaving and intertwining. \\
\hline atonga & $\begin{array}{l}\text { Basket made of wicker in a twinned weave, commonly used } \\
\text { for transporting harvested grain from the fields. }\end{array}$ \\
\hline odheru & $\begin{array}{l}\text { Dish-shaped basket similar to a large tray, made of wicker } \\
\text { and used for transporting and winnowing grain. }\end{array}$ \\
\hline osech-winy & Non-return trap, used for catching birds. \\
\hline osech-rech & Non-return cage, used for fishing. \\
\hline lweru & $\begin{array}{l}\text { Cradle-shaped basket, made of sisal ropes and used for fish- } \\
\text { ing. }\end{array}$ \\
\hline rimba or gogo & Large, long fish basket or net, used for fish drives. \\
\hline
\end{tabular}

Without using pictorial illustrations, it would obviously be impossible to explain the differences between these various baskets. The illustrations below have been reduced to their fundamentals and would therefore be compact enough to be included in a dictionary. To a large extent these illustrations are realistic and even if a particular basket has never been seen, this lack of prior knowledge would not hinder an understanding of what is being defined. The illustrations are also simple and precise. In addition to this, they have clarity and are easily distinguished. They therefore meet the criteria for pictorial illustrations as proposed by Al-Kasimi (1977). Furthermore, they possess distinguishing properties and thus establish the concept basket more efficiently than a verbal equivalent would be able to do. Moreover, the verbal equivalents require an uneconomical number of words and may not show the spatial or sequential relationships effectively. 

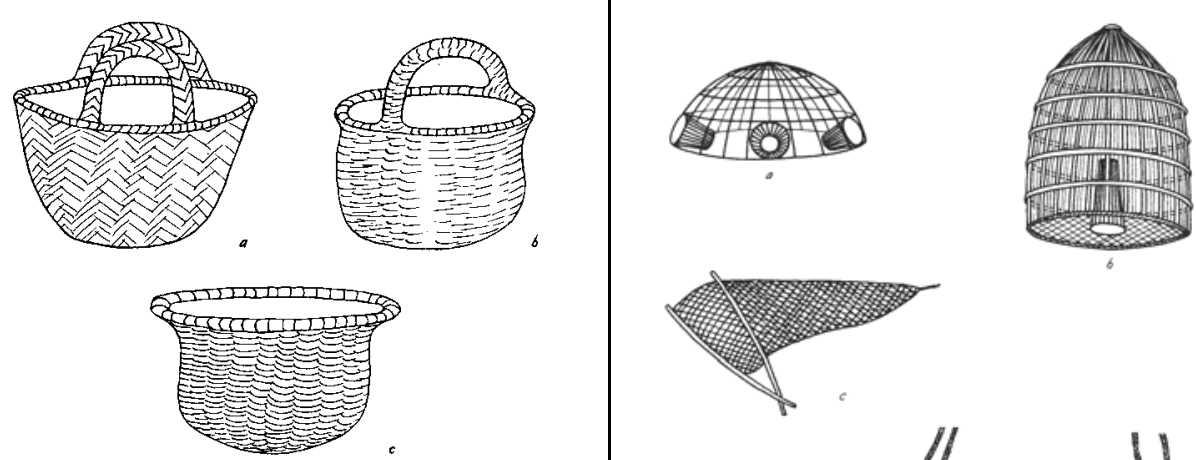

is
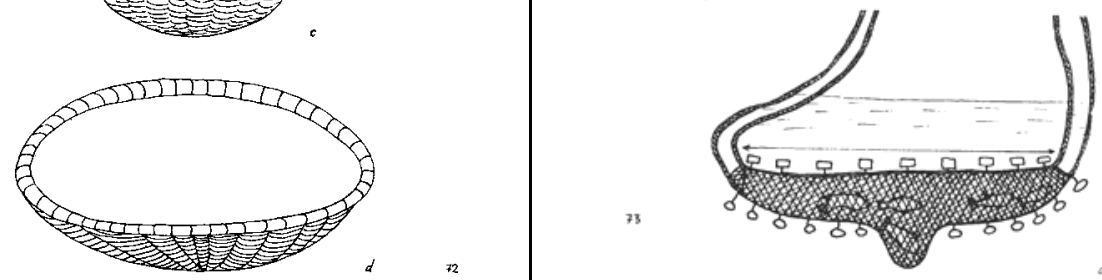

Figure 1: Baskets for general use

a. A vegetable basket (okapu)

b. A market basket (aduda-biye)

c. A basket for transporting grain from the fields (atonga)

d. A winnowing tray (odheru)

Figure 2: Baskets with special uses

a. A bird trap (osech-winy)

b. A fish basket (osech-rech)

c. A cradle-shaped basket (lweru)

d. A large long fish basket (in Lango) or fish net (in Kadem and other southern Luo tribes) (rimba or gogo)

\section{Cattle types of the Batswana}

According to Breutz (1991: 15), the Batswana people exclusively breed the longhorn cattle for the size of their horns and their colour which arouses the enthusiasm of the men, chiefly serve as sacrificial animals and supply the essential portion of bride wealth. This possession constitutes the economic wealth of their owner. The cattle have different names depending on the colour of and patterns on their skin. In Thanodi ya Setswana the different kinds of cattle are included in the back matter of the dictionary. The lexicographer has used full colour photographs of the various kinds of cattle so that the dictionary user will clearly see the differences between the various kinds of cattle.

Due to the fact that the names of the different kinds of cattle are derived from the colour of and patterns on their skins, the use of photographs provides realistic illustrative material which has fidelity. The illustrations are simple, and not open to double interpretation. They are precise as the user's attention is directed only to the colour of and patterns on the skins of the cattle, which is what is relevant to the specific concept. The illustrations are also completed by captions providing the names of the particular kinds of cattle. Furthermore, the 
dictionary user easily distinguishes the features of the illustrations thus indicating that they have clarity.

As they cue and reinforce the verbal equivalents, especially when the dictionary user can identify and respond to the photographs, these illustrations serve the functions proposed by Gropper (1963). They also serve as examples as several different but relevant photographs have been given in order to establish the concept of the different names for different kinds of cattle depending on the colours of and patterns on their skins. Landau (1989: 112) states that photographs are necessary in the case of unidealized individual things. From these photographs, it can clearly be seen how the use of pictures depicting different concepts, particularly in African language monolingual and bilingual dictionaries, can go a long way in actually showing the dictionary user the differences that would be very difficult to describe verbally.

According to Bergenholtz and Tarp (1995: 156), encyclopaedic sections may be explicitly or implicitly integrated in the word list, depending on whether direct cross-references are made from the individual dictionary articles or on whether such references are understood. However, in the Thanodi ya Setswana, there are no cross-references to or from the central word list. The illustrations may therefore be included to serve a supplementary function and are comparable to the colour plates in earlier encyclopaedias.

The use of these two examples does, however, not mean that objects such as baskets and cattle are the only items that should be illustrated in dictionaries. There are also other cultural artefacts as well as initiation and religious rituals and marriage and cleansing ceremonies.

\section{Conclusion}

On the basis of the research described above, it can be concluded that not only pedagogical dictionaries do and should include illustrations. Other dictionary types may also include illustrations, for instance, bilingual and multilingual dictionaries with significant differences between the cultures of the speakers, for instance, the South African Multi-language Dictionary and Phrase Book, and, in addition to this, monolingual dictionaries for languages embedded in cultures that have not given way to popular culture but have retained their customs, traditional norms and values like the Luo people of East Africa and the Setswana people of Southern Africa. This is important due to the fact that dictionaries for many African languages are being compiled for the first time and that because of limited resources, these languages do not have different types of dictionaries, for instance, overall descriptive, standard or pedagogical dictionaries. For many of the African languages, a standard monolingual dictionary is still non-existent. As a result, African language dictionaries have to serve many purposes simultaneously. Their target audience ranges from mother-tongue speakers and learners, to children and scholars. For these reasons, it would 
make these dictionaries accessible to a wider audience if lexical items for cultural concepts could be illustrated.

According to Al-Kasimi (1977: 99), the past experiences of the perceiver play an important role in the process of perception when he/she is familiar with the object pictured. But when the object pictured is new to the perceiver, it is the stimulus properties of the picture which will be the determining factor in the formation of the concept. Accordingly, pictorial illustrations can be employed in the bilingual dictionary to illustrate objects familiar to the user as well as those cultural items which are peculiar to the foreign learner.

On the basis of this study, it can be said that, in general, pictorial illustrations add to the communicative value of dictionaries, help in bridging the semantic gaps that may occur between languages and save space which would otherwise be taken up by long descriptions of a lemma.

The relative limited research done on pictorial illustrations in the lexicographical, particularly African language lexicographical field, made it difficult to limit theories and principles to lexicography per se and a great deal of borrowing had to be done from other fields. The scope of the study had also to be limited as this is a broad field that needs much more research. This study touches on the basis of inclusion of pictorial illustrations in dictionaries, particularly African language dictionaries which are still being developed for some of the languages.

However, further analysis of pictorial features should be done in order to develop and cultivate the culture of the inclusion of pictorial illustrations in dictionaries so that their explanatory value will be realised by lexicographers.

\section{Bibliography}

\section{Dictionaries}

Abraham, R.C. 1958. Dictionary of Modern Yoruba. London: University of London Press.

Benson, T.G. (Ed.). 1964. Kikuyu-English Dictionary. Oxford: Oxford University Press.

Botne, R. and A.T. Kulemeka. 1995. A Learner's Chichewa and English Dictionary. Cologne: Rüdiger Köppe.

Brown J.T. 1925. Setswana Dictionary Setswana-English/English-Setswana. Gaborones: Botswana Book Centre.

Bryant, A.T. 1956. An Abridged English-Zulu Wordbook. Eighth Edition. Mariannhill: Mariannhill Mission Press.

Bullen, H.B. 1951. Zande English Dictionary. London: The Sheldon Press.

Capen, C.A. 1998. Bilingual Dholuo-English Dictionary Kenya. Tucson: Carole A. Capen.

Cuenod, R. 1991. Tsonga-English Dictionary. Braamfontein: Sasavona Publishers and Booksellers.

Corbeil, J.C. and A. Archambault. 1994. The Macmillan Visual Dictionary: Multilingual. Montreal: Éditions Quèbuec/Amérique Inc.

Cowie, A.P. (Ed.). 1989. Oxford Advanced Learner's Dictionary of Current English. Fourth Edition. Oxford: Oxford University Press. 
Dekker, A.M and J.H. Ries. 1958. Woordeboek Afrikaans-Zoeloe Zoeloe-Afrikaans/Isichazimazwi Isibhunu-IsiZulu IsiZulu-Isibhunu. Johannesburg: Afrikaanse Pers.

De Schryver, G.-M. and N.S. Kabuta. 1997. Lexicon Cilubà-Nederlands. Ghent: Research Centre for African Languages and Literatures (Recall), University of Ghent.

De Schryver G.-M. and N.S. Kabuta. 1998. Lexicon Cilubà-Nederlands. Ghent: Research Centre for African Languages and Literatures (Recall), University of Ghent.

Doke, C.M., J.M Malcolm, J.M. Sikakana and B.W. Vilakazi. 1990. English-Zulu/Zulu-English Dictionary. Johannesburg: Witwatersrand University Press.

Education and Training ISCOR. 1966. Woordeboek Afrikaans-Fanakalo/Dictionary English-Fanakalo/ Lo Buk Ka Lo Izwi-Fanakalo-Sibulu-Singis. Pretoria: ISCOR.

Eise, B. and W.H. Haacke. 1999. Khoekhoegowab Language of Damara, Haillom and Nama. Windhoek: Gamsberg Macmillan Publishers.

Fisher, A., E. Mdala, S. Tshabe and E. Weiss. 1985. English-Xhosa Dictionary. Cape Town: Oxford University Press.

Grobler, G.M, J.C. le Roux, L.E. Jennings, R.H. Moeketsi and P.C. Taljaard. 1995. The Concise Multilingual Dictionary. Johannesburg: Ad Donker Publishers.

Kgasa, M.L.A. and J. Tsonope. 1995. Thanodi ya Setswana. Gaborones: Longman Botswana.

Kriel, T.J. 1965. Pukuntšu Noord-Sotho-Afrikaans / Afrikaans-Noord-Sotho Woordeboek. Pretoria: Dibukeng.

Kriel, T.J. 1976. Popular Northern Sotho Dictionary. Northern Sotho-English/English-Northern Sotho. Pretoria: J.L. van Schaik.

Kriel, T.J. 1977. Pukuntšu Noord-Sotho-Afrikaans / Afrikaans-Noord-Sotho Woordeboek. Pretoria: J.L van Schaik.

Kriel, T.J. 1988. Popular Northern Sotho Dictionary. Third Edition. Pretoria: J.L. van Schaik.

Librarius Felicitias. 1986. Learner's English-Venda Dictionary Illustrated in Colour. Johannesburg: Librarius Felicitias.

Louwrens, L.J. 1994. Dictionary of Northern Sotho Grammatical Terms. Pretoria: Via Afrika.

Mantzel, D. and B. Schulz (Eds.). 1997. Illustrated School Dictionary for Southern Africa. Cape Town: Francolin Publishers.

Matumo, Z.I. 1993. Setswana-English-Setswana Dictionary. Gaborone: Botswana Book Centre and Macmillan Botswana Publishers.

McLaren, J. 1963. A New Concise Xhosa-English Dictionary. Cape Town: Maskew Miller Longman.

Nesbitt, R. 1996. Chambers-Macmillan South African Dictionary, Junior Primary, Illustrated. Manzini: Macmillan Boleswa Publishers.

Paroz, R.A. 1961. Southern Sotho-English Dictionary. Revised and Enlarged Edition. Morija: Morija Sesuto Book Depot.

Prinsloo, D.J. and B.P. Sathekge. 1996. New Sepedi Dictionary English-Sepedi (Northern Sotho)/Sepedi (Northern Sotho)-English. Pietermaritzburg: Shuter and Shooter.

Prinsloo, D.J. and B.P. Sathekge. 1997. Popular Northern Sotho Dictionary. Cape Town: Pharos Dictionaries.

Prinsloo, D.J, B.P. Sathekge and E. Kapp. 1997. Nuwe Sepedi Woordeboek Afrikaans-Sepedi (NoordSotho/Sepedi (Noord-Sotho)-Afrikaans. Pietermaritzburg: Shuter and Shooter.

Reynierse, C. (Ed.). 1996. South African Multi-language Dictionary and Phrase Book. Cape Town: Reader's Digest Association of South Africa. 
Rycroft D.K. 1981. Concise SiSwati Dictionary SiSwati-English/English-SiSwati. Pretoria: J.L van Schaik.

Sanderson, G.M. 1954. A Dictionary of the Yao Language. Zomba: The Government Printer.

Snyman, J.W., J.S. Shole and J.C. le Roux. 1990. Dikisinare ya Sestwana-English-Afrikaans Dictionary/Woordeboek. Pretoria: Via Afrika.

Summers, D. (Ed.). 1987. Longman Dictionary of Contemporary English. New Edition. Harlow: Longman.

Taasisi ya Uchunguzi wa Kiswahili Chuo Kikuu Dar es Salaam. 1981. Kamusi ya Kiswahili Sanifu. Nairobi: Oxford University Press.

Taasisi ya Uchunguzi wa Kiswahili Chuo Kikuu Dar es Salaam. 1990. Kamusi Sanifu ya Isimu na Lugha. Dar es Salaam: Educational Publishers and Distributors.

Taasisi ya Uchunguzi wa Kiswahili Chuo Kikuu Dar es Salaam. 1996. TUKI English-Swahili Dictionary. Kamusi ya Kiingereza-Kiswahili. Dar es Salaam: Taasisi ya Uchunguzi wa Kiswahili (TUKI).

Turner, Wm. Y. 1996. Tumbuka/Tonga-English/English-Tumbuka/Tonga Dictionary. Blantyre: Central Africana Ltd.

Vallardi, A. 1992. Italiano-Swahili/Swahili-Italiano. Italy: Garzanti Editore.

Van Warmelo, N.J. 1989. Venda Dictionary English-Tshivenda. Pretoria: J.L van Schaik.

Ziervogel, D. and P.C. Mokgokong. 1979. Klein Noord-Sotho Woordeboek. Third Edition. Pretoria: J.L van Schaik.

\section{Other sources}

Al-Kasimi, A.M. 1977. Linguistics and Bilingual Dictionaries. Leyden: E.J. Brill.

Bergenholtz, H. and S. Tarp (Eds.). 1995. Manual of Specialised Lexicography: The Preparation of Specialised Dictionaries. Amsterdam/Philadelphia: John Benjamins.

Breutz, P.-L. 1991. The Social and Political System of the Sotho-Tswana. Four Generations of Traditional Culture Change. Ramsgate: P.-L. Breutz.

Brown, H.D. 1987. Principles of Language Learning and Teaching. Englewood Cliffs: Prentice-Hall Inc.

Carstens, A. 2001. Principles of Document Design. Class Notes. Pretoria: University of Pretoria.

Casson, R.W. 1981. Language, Culture, and Cognition: Anthropological Perspectives. New York/London: Macmillan.

Fleming, M. 1967. Classification and Analysis of Instructional Illustrations. AV Communication Review 15: 246-258.

Gouws, R.H. 1989. Leksikografie. Cape Town: Academica.

Gouws, R.H. 1994. Ostensiewe adressering in vertalende woordeboeke. Lexikos 4: 61-85.

Gropper, G.L. 1963. Why a Picture is Worth a Thousand Words. A V Communication Review 11: 7695.

Landau, S.I. 1989. Dictionaries: The Art and Craft of Lexicography. Cambridge: Cambridge University Press

Ndoleriire, O.K. 2000. Cross-cultural Communication in Africa. Webb, V. and E. Kembo-Sure (Eds.). 2000. African Voices. An Introduction to the Languages and Linguistics of Africa: 268-285. Cape Town: Oxford University Press.

Ocholla-Ayayo, A.B.C. 1980. The Luo Culture: A Reconstruction of the Material Culture Patterns of a Traditional African Society. Wiesbaden: Steiner. 
Putter, A.M. 1999. Verklaringsmeganismes in kinderwoordeboeke. Unpublished M.A. Thesis. Potchefstroom: University of Potchefstroom.

Stein, G. 1991. Illustrations in Dictionaries. International Journal of Lexicography 4(2): 99-127.

Swanepoel, P.H. 1990. Definisies in vakkommunikasie. Pretoria: HSRC.

Tylor, E.B. 1871. Primitive Culture: Researches into the Development of Mythology, Philosophy, Religion, Art and Custom. 2 volumes. London: John Murray.

Zgusta, L. 1971. Manual of Lexicography. The Hague: Mouton.

Zgusta, L. 1988. Pragmatics, Lexicography and Dictionaries of English. World Englishes 7(3): 243253. 